\title{
Higher Education Quality Assurance System in Latvia
}

\author{
Dr. TATJANA VOLKOVA, LASMA LANCMANE
}

Banking Institution of Higher Education, Latvia

\section{Introduction}

As the important part of European integration there is a goal till the year 2010 to create the unite higher education area, which means: considering the needs of European labour market in designing and improving study programs; encouraging the students and staff mobility within the unite higher education area; unification of the systems of evaluation of students' knowledge and skills acquired; increasing the competitiveness of the European universities; unification and implementation of criteria for quality evaluation of universities and study programs in Europe.

The Bologna declaration has started a new stage in the development of the higher education area. There has to be a unite responsibility for disseminating the idea of Bologna declaration and encouraging it's implementation in practise in each country which joined the declaration. The European enlargement encourages discussions and shares information among ministries, universities and society about the further ways of improving the quality efficiency and social responsibility of Universities in reaching the goals of the European Union.

Quality assurance is a basic issue in the Bologna declaration. The Bologna's declaration could be considered as the one of the most important supporting instrument in the further improvement of higher education quality, showing that the higher education quality has the European dimension and it is not only responsibility and issue for national country. It helps in understanding that by signing 
the Bologna declaration universties have agreed to create the unite higher education area in Europe by respecting the diversity of national context and subject areas.

Majority of higher education institutions in Latvia has been involved in Bologna process, but still a lot of work need to be done to improve the awareness of academic staff and students in implementation of the declaration ideas in practise.

Quality assurance is one of the fields where Latvia has achieved recognized results and at the moment is ahead of a number of other Bologna process countries. Accreditation of higher education institutions and study programmes by involvement of foreign experts in evaluation teams started in 1996 and now is successfully introduced in Latvia. (6.)

Key words: European higher education area; higher education quality assurance system; accreditation process; self-evaluation report

After restoration of independence of Latvia in beginning of 90-ies in a relatively short period the foundation of market economy was created. It led to good macroeconomic preconditions for the further development of national economy and technological innovation. The structure of economy, including manufacturing, consumption and labour force, was transferred considerably.

This, in turn, has enhanced the increasing role of quality of education system in improving efficiency of companies' activities. Thus, Quality Management has become a hot issue of higher education system in general, and in each single higher educational institution in particular.

The Latvian Higher Education quality assurance system was established in mid 1990s simultaneously with systems in Estonia and Lithuania. The series of seminars were organized for the three Baltic States by the Council of Europe Legislative Reform programme in 1994-1995 to introduce the idea of quality assurance system. 
Well-known European quality assurance experts were chosen as speakers at this seminar and participants were selected from leadership of higher education institutions and high-ranking ministry officials from Estonia, Latvia, and Lithuania. The need to establish quality assurance system was widely discussed and it was agreed that Baltic countries should cooperate in establishment of quality assurance systems with the view to establish comparable criteria and procedures in all the three countries and to further use each other's experts in the evaluation teams.

It was decided that Baltic States will co-operate in the assessment, but the decisions towards the system introduction will be taken by each country individually. The reason for such decision was very obvious due to the fact that the three Baltic countries are too small to work on purely internal quality assessment system. For example, there are certain studies fields were only 1-2 study programs exist per country (i.e. in engineering, medicine, etc.). This clearly indicates a need for foreign experts in the evaluation teams. Usage of experts from other two Baltic states is very favourable because, firstly, the countries have similar past and development and therefore the experts can easily understand the achievements, secondly, the travel costs are considerably less due to the short travelling distances of experts.

Thus, according to the Declaration on Co-operation in Quality Assurance of Higher Education in the Baltic States of October 25, 1994, the quality assessment in all three Baltic States is carried out using international peers from the three Baltic States and beyond. In Latvia the team consists of at least three experts out of whom only one comes from Latvia. In most cases the one of the other two experts comes from the Baltic States, and the other - usually from Western Europe, sometimes from USA, in some cases from Eastern Europe.

Accreditation is a part of the higher education quality assurance system, which, together with self-evaluation and evaluation by outside experts, forms the main stages of a continuous quality assurance process. Accreditation of higher education institutions in Latvia takes place according to the Law on Higher Education Establishments (LHEE), adopted by Saeima (The Parliament of the Republic of Latvia) 
on November 2, 1995. Article 9 of the law stipulates the general accreditation principles of higher education institutions (HEI).

According to the LEEE of 1995 a two-stage system of quality assurance was created in Latvia. License gave the right to start admission of students to the programme in question awarding qualification in the name of higher education institutions only. Accreditation was established as evaluation of the quality of organization and resources, as a result of which institution in question gains a status of a staterecognized higher educational institution. (5.)

Requirements to the study programmes and $\mathrm{HEI}$ as well as the most important organizational aspects related to accreditation are reflected in the Accreditation Regulations for HEI (AREG) approved by the Cabinet of Ministers on November 28, 1995. Recommendations for application of these rules are elaborated by Baltic Higher Education Coordination Committee (BHECC).

The regulations for the higher education quality assurance are the same for the university and non-university sector organizations but the approach should be different. The study programmes should be evaluated according to their specific aims and objectives. The members of the external expert team also should be chosen according to the specific tasks of the evaluation.

In order to organize the process and to assist higher education institutions in their self-assessment, the Higher Education Quality Evaluation Centre (HEQEC) (www.aiknc.lv) was established in the end of 1994. The shareholders of HEQEC are Ministry of Education and Science and according to the decision made by the Council of Rectors five higher education establishments: University of Latvia, Riga Technical University, Latvian Academy of Medicine, Daugavpils Pedagogical University and Business Institute "Turiba".

The activities of the HEQEC are supervised by the Board consisting of five members. One member is appointed by the Ministry, one by the University of Latvia and one by Riga Technical University, while two other members are elected by the meeting of the shareholders. 
The day-to-day activities of the HEQEC are entrusted to the Director elected by the meeting of the shareholders. Employees of the HEQEC are appointed by the order of the director. Today the personnel of the HEQEC consist of two full time employees, including director, and two part time employees. According to the Statutes the HEQEC has following objectives:

- to work out and co-ordinate the procedures aimed at quality assessment of higher education institutions and study programmes as well as preparing peer visits in compliance with the Law on Education of the Republic of Latvia and the Law on Higher Education Institutions;

- to organize the quality assessment of higher education institutions and study programmes on behalf of the Ministry for Education and Science; - to set up commissions and working groups responsible for solving problems related to quality assessment and accreditation; - to invite foreign experts for peer visits to higher education institutions; - to sum up and to make public the experience obtained as the system of higher education institution and study programmes' quality assessment is being set up and implemented.( $\underline{3 .}$ )

There are several stages in the accreditation process:

1. Preparation of self-assessment report.

2. Sending the self-assessment report to experts for evaluation and writing the assessment report and after the visit to the University submitting to the Accreditation committee.

3. Decision made by Accreditation committee.

The first stage of quality assessment is a self study by the institution and compiling of the self-assessment report. The self-assessment is a necessary pre-condition and the first step of the accreditation of the higher education institution. The creation of the permanently acting quality assurance and improvement system, based on the self evaluation, is the main goal of the accreditation. 
The self-assessment report is long process where at the beginning a steering group should be set up, with a wide spectrum of members. They are from different groups: administration, academic staff, and students. At the quality assessment process one of the requirements for the completion of the self-evaluation report is to provide a comparison with at least two similar programmes in the EU member states thus providing a space for some kind of benchmarking. The self-assessment report not exceeding 30 pages must be prepared by the HEl. Documents describing the premises and facilities of the institution, its long-term development plans, financial documents and those certifying the property relations and explaining the governance of the institution can be appended to the selfassessment report, but it is suggested to add a list with names of these documents and information, where, when and how to receive these documents. The CVs of the academic staff and at least short description of all study courses must be appended. The second stage is that the self-assessment report is sent out to experts, who study it before they come to a site visit to the institution. After the site visit, they write an assessment report and submit it to the Accreditation committee which is a body appointed by the Minister.

Public discussion of the preliminary report of Evaluation Commission report must be organized at the end of expert visit in the place where accreditation is being carried out. The precise Evaluation Commission final report and all individual reports of experts are submitted to Higher Education Council or Accreditation Commission which decide to give accreditation or not. After the decision the Evaluation Commission final report is published in newspaper "Education and Culture". All self evaluation reports and Evaluation Commission's final reports are available at Higher Education Quality Evaluation Centre.

The third stage is that Accreditation committee takes decision regarding the accreditation. Assessment and accreditation are carried out for each study programme and for an institution.

The assessment of study programmes includes 6 main aspects and 14 questions. They are as follows: 


\section{Aims and objectives of study programme}

1. Possibility to understand, to reach and to control the aims and objectives defined by the study programme.

\section{The content and organization of the studies}

2. Complying with the professional and education standards, legislation of the Republic of Latvia and with the requirements and standards of the European Union.

3. Consistency of the study programme and its parts with the demands to create the common European education space, including the comparison with at least two study programmes from EU countries.

4. Qualification and professionalism of the academic staff members.

\section{Assessment of teaching and learning}

5. Modern methodology of teaching, a clear statement of results to be expected, problem solving, use of computers, internet, audiovisual and multi media equipment.

6. Counselling and guidance for students, academic supervision and consultations of the teaching staff, increasing of the students' motivation to study.

7. Methods to assess the knowledge, skills and attitudes, their objectivity use to improve the studies.

\section{The management and support of the studies}

8. Respect of the principles of democracy, clear definition of the relations among representatives of the administration, academic staff and students;

9. Cooperation with other higher education establishments, research institutions, international organizations; exchange of staff and students with other higher education establishments.

10. Methodological, informational and technical resources and facilities of the study programme.

\section{Research (creative) activities of the staff and the students}

11. Involvement of the academic and general staff in the research (creative) activities, up to date character and connection with the content of the study programme.

VI Quality assessment and mechanisms to ensure it 
12. Annual self-assessment of the study programme, evaluation of the strengths and weaknesses, changes, plans and possibilities for the development, continuously action of the system of self-evaluation and quality improvement.

13. Successful work of graduates according to their qualification.

14. Opportunities to continue studies and financial guarantees in the case of closure of the programme, its re-organization and other changes.

The assessment of programmes and institutions carried out by external experts is recommended to evaluate all aspects listed below by a mark according to the certain scale and to add a short comment. Evaluation scale is from 1- 4 where 4 is excellent, 3 - highly satisfactory, 2 - satisfactory, 1 - not satisfactory. In case of negative evaluation (mark 1) the comment is compulsory. It is recommended to add short description about each quality aspect: strengths, weaknesses, opportunities and threats. It is possible to leave without the mark a question; about which expert is not competent. The filled in questionnaire expert must add to the reports - individual and joint. This questionnaire can also be used as a plan for the evaluation report.

The assessment of higher education institutions includes 5 main aspects and 12 questions. They are as follows:

\section{Aims and objectives of higher education institution}

1. Possibility to understand and to reach the aims and objectives defined by the higher education institution. The connection between the aims and objectives with national aims and objectives, with requirements of science, with aims and objectives of the academic staff of the institution and with interests and needs of the students.

\section{The organization and management of studies}

2. The conditions for studies, leisure and living conditions of the students ensuring a system of matriculation equal for all candidates, guidance and counselling for students, motivation to study, opportunities to acquire knowledge and skills not foreseen by the study programme.

3. Research done by students as a part of the teaching process, student research associations, competitions of student research work, awards, prizes, special scholarships. 
4. International cooperation, exchange programmes, inviting visiting lecturers, exchange of staff members and students with other higher education institutions, possibilities for the practical placements of students in Latvia and abroad.

\section{Academic staff}

5. Adequate qualification of the academic staff and its compliance with the requirements of legal norms (the amount of teaching done by teachers with doctor and habilitated doctor scientific degrees (at least $30 \%$ at higher education institutions, $50 \%$ at universities).

6 . The up to date character of the research area, coordination of the research and cooperation with other research institutions in Latvia and abroad. The involvement of the research staff of the higher education institutions in the teaching process.

\section{The management of the higher education institution and provision with materials, informational and financial resources}

7. Implementation of the principles of autonomy and democracy at the institution, the rights and duties of the students concerning the academic process at the institution. Internal quality control, the system of election and of upgrading academic and general staff of the institution.

8. Informational systems and opportunities for exchange of information in national and international networks, laboratories available that allow students to become familiar with modern technologies, employment of qualified auxiliary staff.

9. Availability of necessary financial resources to implement the objectives of the institution and its long-term development plan.

\section{Quality assessment}

10. The continuous action of the quality assessment and improvement system in the higher education institution, creation and discussion on the long-term development plans.

11. The opportunities for the graduates on the labour market.

12. The opportunities to continue studies and financial guarantees in the case of a closure, a re-organization or other changes of the study programmes.

The decision on accreditation is made by the Council for Higher Education (for higher education institutions' accreditation) or the Accreditation Commission set up by the Ministry for Education and Science (for accreditation of study programmes) after 
hearing the recommendations of the Evaluation Commission. The foreign members of the Evaluation Commission have to read the self-assessment report that should be handed over in Latvian and in English (or in one other foreign language) and go for two days visit to the higher education institution to be accredited. Evaluation committees consist of one expert from Latvia and at least two experts from EU, Estonia, Lithuania or another foreign country.

In order to have the rights to issue graduation diplomas recognized by the state HEI should have the certificate of accreditation, confirmation of the statutes (satversme) and the rector of a higher educational establishment in accordance with the procedure envisaged by the Law on Higher Educational Establishments the higher educational establishment. The accreditation proceeds in accordance with the regulations on accreditation approved by the Cabinet of Ministers. Only those higher educational establishments who have been accredited and which offer state accredited study programmes have the right to issue diplomas of higher education recognized by the state to its graduates. If there are found substantial drawbacks in the process of assessment of a higher educational establishment or study programme, HEI can be temporarily accredited for two years. Subsequently a second accreditation shall be performed. In case the Council of Higher Education and the Accreditation Commission give a negative assessment of a higher educational establishment as well as all the study programmes thereof, it shall be denied accreditation. The following shall qualify as reasons for refusal:

- the submitted documents do not comply with law or other legal acts; - the qualifications of the academic staff are not sufficient; - the premises are not up to standards advanced for higher educational establishments;

- the higher educational establishment does not make available study laboratories which would allow the students to master contemporary technologies of work; (3.) If the repeated negative evaluation is given the accreditation refusal shall be final and the Council of Higher Education or the Accreditation Commission shall submit a recommendation to the Minister of Education and Science to either reorganize or liquidate the higher educational establishment. 
The results of accreditation stating the reasons for refusal of the accreditation or are published in the newspapers.

Quality assessment is an ongoing process and all the higher education programmes in Latvia have been assessed first time by the year 2002 and once in every six years afterwards. The first round of quality assurance-accreditation in Latvia was completed in November, 2001.

\section{Conclusion}

Bologna declaration depicts the strong emphasis on the idea that the education should give the knowledge and skills for graduates to raise their competitiveness in the labour market. This brings closer universities and non-universities as the necessity is to tailor their programmes accordingly to the demands from labour market. There is discussion on should there be any division in professional programmes and academic or not. There is a tendency to approximate both universities and HEI.

The great challenge facing educational leaders in Baltic countries is being ready for continuous change in higher education. In May 2004 all three countries are becoming the members of the European Union. The fact raises a lot of questions in higher education. How ready are HEI in Baltics to compete within EU HEl, will it enlarge students' outflow, are diplomas recognized in EU? One of the answers to that is what it depends on quality of education provided.

The quality assurance consists of many aspects. Accreditation and self-evaluation can be considered as part of the process.

Self - evaluation is the important part of the accreditation process. It provides opportunity to reflect upon basic aspects of teaching, research and administrative aspects. The accreditation process is rather expensive and has a campaign character. It would be wise to carry out the next accreditation after six years based on the university self assessment reports which are tailored for each programme each year. It would make process easier and less expensive. 
The evaluation process should be also an ongoing learning process for all involved parties. External experts should be first of all advisers, supporting the creation and activities of internal quality assurance system in higher education establishments.

It is necessary to organize seminars to educate all involved parties where everybody could benefit and improve the process by common effort.

Information about the accreditation system and its results in Latvia should be disseminated and ensured that other European countries know and respect the results achieved. The higher education in Europe will become more transnational and therefore it is necessary to think about common assessment criteria and procedures. It would be necessary to take into account foreign accreditation of programmes or institutions in order to make education comparable and competitive by establishing common database of accredited programmes and institutions, indicating the accreditation body, likewise it is on national level.

\section{References}

[1] Bush, T. and Bell, L. (2003) The Principles and Practice of Educational Management, Paul Chapman Publishing, London

[2] Bennet, N. and Glatter, R., Levacic, R. (1994) Improving Educational Management through research and consultancy, Paul Chapman Publishing, London

[3] Dzelme J. Higher Education Quality Evaluation Center. - www.aiknc.lv

[4] Everard, K.B. and Morris, G. (1996) Effective School Management, Paul Chapman Publishing, London

[5] Rauhvargers A. Latvia in Bologna process. Report on reforms in Latvia's higher education on the way towards European Higher Education Area. R., 2003. www. aic.lv

[6] Rauhvargers A. Jopint degree study -in: C. Tauch and A. Rauhvargers Survey on Master degrees and Joint Degrees in Europe, EUA, Brussels, 2001, pp. 2744.

[7] Self - Assessment. Guidelines for public sector. EFQM.1997

[8] Manual of Quality assurance: procedures and practices, European Training Foundation, November 1998. 